dence of observations in Saskatchewan, assembled from the records with the help of E. Manley Callin, C. Stuart Houston and Robert W. Nero, would lead us to define the status of the species in this province as follows: uncommon summer visitant in the south, possibly even breeding in the extreme southeast. It would be most desirable to get a definite breeding record for the species in Saskatchewan.

\section{LITERATURE CITED}

A.O.U. Committee. 1957. Check-list of North American birds. 5 th ed. Baltimore.

Belcher, Margaret. 1958. Bird notes from a farm shelterbelt. Blue Jay, 16:101-104.
Belcher, Margaret. 1961. Birds of Regina. Special Publication No. 3, Sask. Nat. Hist. Society, Regina.

Houston, S. 1950. Scarlet Tanagers. Blue Jay, $8: 13$.

Macoun, J. 1900. Catalogue of Canadian birds. The Queen's Printer, Ottawa.

Mitchell, H. H. 1924. Birds of Saskatchewan. Can.Field-Nat., $38: 101-118$.

Myres, M. T., ed. 1965. Bulletin No. 35, Calgary Bird Club. Dept. of Biology, University of Alberta, Calgary. Mimeo.

Salt, W. R., and A. L. Wilk. 1958. The birds of Alberta. The Queen's Printer, Edmonton.

Seton, E. E. T. 1886. The birds of western Manitoba. Auk, $3: 324$.

Thompson, E. E. [E. E. T. Seton]. 1891. The birds of Manitoba. Proceedings of the U.S. Nat. Mus., $13: 457-643$. Washington, D.C.

\title{
NOTE ON THE WESTERN TANAGER AT REGINA
} by Hugh C. Smith, Regina

On May 12, 1965 I observed what I took to be a male Western Tanager (Piranga ludoviciana). The bird was seen flying about in the trees that line the square of the RCMP barracks in the city of Regina, and it drew my attention away from the Baltimore Orioles in the vicinity because of its vivid orange-red head which contrasted sharply with its yellow body and black wings. Because $I$ was on my way to work I was "unable to pursue the bird for any length of time. Once at work I telephoned my wife and gave her a verbal description of the bird I had seen. After consulting Peterson's Field guide to western birds, she confirmed my thoughts that it was a Western Tanager. She also advised that it was recorded as being in Saskatchewan in Peterson's guide and in the Field check-list of Saskatchewan birds, but that no mention of it was to be found in Belcher's Birds of Regina (1961). Here the matter rested until another observation of a male Western Tanager was brought to my attention.

On May 20, 1965, again at the RCMP barracks, a number of persons called my attention to a strange bird that was flying about the trees outside their office window. I was able to identify it as a male Western Tanager in spring plumage. On this occasion it was very carefully observed and was easily compared to the Baltimore Orioles with which it was associating. The next day I brought my Peterson's guide to work and showed the illustration of the Western Tana- ger to those who had seen the strange bird and they agreed that this was the bird that they had seen the day before. It is to be noted from the December 1964 issue of the Blue Jay (p. 155) that the previous early date for recording this species in Saskatchewan was May 13. These two observations could have been observations of the same bird, but because of the time difference between the two sightings I am inclined to think that two separate birds were observed.

Editor's Note: The Western Tanager is not listed in the Birds of Regina, but the reporting of Smith's 1965 observations makes this an appropriate time to refer to a sight record for Regina reported to the author just as the book was going to press. On June 1, 1961 Mrs. Helen Tobin saw a bird drinking at her bird bath on Angus Crescent which she believed to be a male Western Tanager, having known this species in the United States. There was no way of verifying this observation, since other observers were not able to locate the bird, and this isolated and unverified record was therefore not included in the Birds of Regina. The following year, 1962, a male Western Tanager was reported as seen by Marion Goudie on May 15, and on May 17 Mrs. Holly Wallace reported a second observation, describing the bird she saw to Frank Brazier as a brilliantly plumaged bird with yellow body, black wings and red head. Again, other observers who went to look for the bird were unable to find it. 